Comunicação e Sociedade, vol. 18, 2010, pp. 41-51

\title{
The postmodern interstices within modernity: interpreting the historical controversy
}

Thomas Seguin"

"I have said and repeated that postmodern did not mean the end of modernism but another linkage with modernity."

Jean-François Lyotard (1988a: 64)

Resumo: Será que existe algo como um postura pós-moderna? Propomo-nos reflectir sobre a postura cultural que está por trás da teoria pós-moderna. Se nos debruçarmos sobre os fundadores desse movimento, percebemos a que ponto a divisão moderno/pós-moderno constitui, de alguma forma, uma dicotomia artificial. Para além dos aspectos descritivos das mudanças sociais envolvidas no pós-modernismo, olhamos para a intenção originária que orienta os autores pós-modernos. A análise desses fundamentos permite-nos penetrar de forma relevante na própria ideia pós-moderna. A novidade pode ser realmente encontrada na postura reflexiva que caracteriza o pós-modernismo na sua conexão interna com a modernidade. Por isso, desenvolvemos a hermenêutica da mudança que os pensadores pós-modernos puseram em prática no que diz respeito à re-leitura e re-escrita de algumas reivindicações modernas. Os pensadores pós-modernos abrem interstícios dentro da modernidade, criando espaços fundamentais para revitalizar a modernidade e promover a imaginação em direcção a novas configurações sócio-históricas.

Palavras-chave: modernidade, pós-modernidade, teoria pós-moderna.

When the scientific community evokes postmodernism, it often refers to the historiographic debate. It is true that the term "post-modern" is confusing particularly if we abandoned hermeneutics. By its etymology, the postmodern appears to contain an obvi-

\footnotetext{
* Phd Sociology. University Montpellier III, IRSA/ CRI/ LERSEM. Assistant Technological Institute of Chalon-sur-saône. University of Burgundy. (tseguin07@gmail.com)
} 
ous formulation which establishes a new era. Nevertheless, articulating the discussion only around the historiographical aspects does not allow reaching an adequate level to analyze what is at stake in the historical criticism of postmodern authors.

Of course, it is certainly possible to analyze each particular field of social activity, to delimit the transition for endorsing a little worn dichotomy. But the task is hard because we still face conflicting interpretations on Modernity. To conclude or support the hypothesis of a transition from modernity to postmodernity, it would be necessary to engage in a very precise description of the multiple layers of social reality. In these interpretations, we would still confront with antagonist views of what specifically stands for modernity, and what represents typically postmodernity. This problem is not anecdotic, because it undermines the more appropriate debate that can be led on the contemporary statute of modernity in these various fields. It contributes to obscuring the real effects that are searched by the postmodern posture in its discourses concerning modernity. Some authors, who calls themselves "modern" tried to unravel the contradiction with a slight distinction between types of modernity which can be reflexive (Giddens, 1990), second (Beck, 2002), or even saturated in a renamed hypermodernity (Lipovestky, 1989). The major distinctions made by these great authors drive us not to explore the postmodern posture in itself, but their attempts to safeguard modern conceptual devices. It results in a profound misunderstanding of the own posture of postmodern authors, on which so many unjustified prejudices are based. Rather, we propose to revert to the roots of postmodern thought, which has irrigated the plural investments in areas of knowledge and fields of activity. By seizing the deep hermeneutic, and the underlying motifs, we attain a better idea of the postmodern gesture, as a global context for highlighting all the individual contexts that derived from the originary intellectual configuration.

\section{The postmodern moment: heuristic or political?}

We need to conceive see "postmodern moment" as an integral part of modernity. Postmodern notions are indeed not extracted from the "modern" to create a sui generis situation. Their conceptualizations arise directly from modern corpus and the achievements of modernity. Although postmodern authors emphasize the imminent ending or the necessary closure of modernity, and invoked the creation of an alternative, they retain a singular linkage with this founding period. It is particularly relevant to note how Lyotard views himself postmodernism not as the end of modernity but as the emerging state of the modern move, insisting on the fact that this emerging moment is recurrent (Lyotard, 1988b: 28). Here we discern how the postmodern posture does not think itself against modernity, but it precisely envisions its motif as embodying the own modern vocation of moving thought and society forward. This can be argued by the postmodern claim for being inheritors of mostly the whole modern critical legacy. Lyotard thus writes that the postmodern is already at work, for a long time, in modernity itself (Lyotard, 1991). In philosophy, the legacy would be found in the criticism of deconstructive thinkers such as Nietzsche or Heidegger. In the cultural sphere, it would be related to architectural and artistic avant-gardes. In politics, postmodern theoriza- 
tions may be inscribed in the radical political traditions that questioned modernization, the Frankfurt School for example.

We can certainly affirm that postmodernists crystallize historical movements that already existed within modernity. On the contemporary scene, they symbolize a long critical tradition both philosophical and esthetical, investigating reason and the rightness of its foundations, as well as assessing its claim to design the organization of society. If we can resume the main items of their critical stance, we should first note that they contest scientific truth as a final objective entity. Postmodernists rather place reason in the socio-historical constructions that have framed its grounding representations, unfolding the inevitable power interests and subjective cultural classifications. With unlocking the iron cage of reason, they attempt to lay reason in a broader historical and sociological scope, setting the objectivization process on larger frameworks that take into account communicative and phenomenological aspects. Instead of subsuming the totality as a reachable goal, they prefer considering its impossible finitude, which fosters pluralization and deepens its referential richness. Analytical frames are not seen as exact representations of reality, because this implies the closure of representation (Rorty, 1979). Yet, only the opening of representation allows enlarging perspectives on reality. It gives room for dissent and contradiction, in one word, difference. Postmodern epistemology opposes itself to the stability of modern science. This latter portraits reality as essentially a non-dynamic feature, it pictures motion as achieved, already constituted and not be done (Deleuze, 1985).

Postmodern science, as Lyotard explains, wishes to reveal the modern presuppositions (Lyotard, 1979). It seeks instabilities that will disturb the reassuring and apparent modern continuity. At these points of contact, it underlines the way totality has neutralized remaining conflicts and excluded some perspectives for the sake of hegemonic or mainstream conceptions of reality. By subverting representations in this way, postmodernists aim at showing how prescriptive denotations are always enshrined even within supposed objective pictures. Thus, they create spacing from where to reflect on the adequacy between reality and representation. Morever, this spacing is framed as an appeal for individuals to involve in a personal experience of critical confrontation with universals. Postmodern science therefore desires to underline the critical and existential intensities lost in the linearity and failures of modern course. Against the univocity of modernity, it is necessary, for them, to revitalize the critical potentials of thought since it awakes critical consciousness as much as existence. The never-ending process of representation offers the opportunity to differ the determination, while giving the possibility for the other to get into the discussion, and, finally, alter what seems to be inalterable at first (Derrida, 1979).

One can think that prejudices against relativism may be relevant; it rests nevertheless that, to a certain extent, this relativist posture can be apprehended as a strategy for fostering social bounds between the plurality of truths of our contemporary societies. Indeed, confronted to the modern breathlessness, postmodernists try to reactivate active citizenship and social cohesion within a knowledge-based debate on modernity and its 
conceptual schemes. The belief is strong among postmodernits that an epistemological change is essential for this endeavor, which may have not been possible using the verticality and totality of modern science. It requires new dispositions of thought, for the differend to emerge about the socio-historical state (Lyotard, 1984). Few critics of the postmodern did read the hermeneutic or heuristic between the lines of sometimes complicated philosophical and sociological blends. Despite this unwillingness, one should combine the thought of the various authors, accumulate the similar epistemological distinctions, and perceive gradually the stratum of a hermeneutic circle. Animating the references, understanding the prescriptive denotations and the rule of different language games are all components of the postmodern moment. However, in a debate for instance, this moment does not belong to any of the two contradictory positions; it only fills the gap between these two. It means that the postmodern moment is a dialectic tool within the contradiction, a specific rhetorical and scientific stance which has to notice the differend, and works out the tension rising whether from the conceptual devices or factual judgments related to the given situation or object. While modern science is driven by an obsessive quest for ultimate truth, postmodern science privileges what Rorty calls an edifying philosophy, that is "the infinite striving for Truth over all Truth" (Rorty, 1979:377). Instead of closing prematurely the discussion about our ways of thinking, the postmodern moment sets processes that put though and action in motion. According to Derrida, deconstructive thought could be compared to a virus, introducing disorder into our concepts, habits or certainties (Brunette\&Wills, 1994:12).

This new scientific approach condemning finitude should be comprehended as the product of modern critical thought. Postmodern thought digs out some of the most substantial and critical aspects of the modern moment itself such as the active force of dissent, the promotion of interpretation as multiplication, the dissemination of reflexive cognitive and communicative practices, the logical intercourse between opposite dualisms, the deepening of complexity related to the multiple layers or reality and the constant dynamic motion in its structure. But, for postmodernists, the critical modernity has been forgotten, diverted from its original roots, and, finally, annihilated in instrumental and scientist positivism, now purely economic and technical. There is indeed a profound historical connection between scientific paradigms and political conceptions of society. Most postmodern authors analyze a one-sided political modernity, which has abandoned the paradigm of human nature that is the legitimacy of the modern project (Morin, 1979), for techno-capitalist efficiency (Lyotard, 1991). In a sense, the metaphysics of development seems to progress without finality, except maybe toward a disincarnated goal. It does not need any finality as it extends itself according to an internal dynamics far away from the ethico-political horizons that lied in native modernity (Lyotard, 1991). Therefore, the spacing we describe as the postmodern moment is an attempt to fill the gap between the ideals of modernity and its empirical and historical achievements (Derrida, 1993). In such a way that, within the spacing, postmodernist thinker could put down again the fundamental questions related to the truth or the rightness of development. Thenceforth that is the modern question itself that would 
be raised again. They refuse the hypostasized conception of modernity, embedded in the notion of "the end of History" (Fukuyama, 1992). Since modern thought is characterized by the constant search for the actual, thought should not rest on its laurels. It must, as much as possible, rethink itself according to the most actual developments of contemporary societies. This applies to the cultural transition of social values, as well as to the frame of Nineteenth- Century political ideologies or early Twentieth-Century scientific epistemologies.

The incredulity towards metanarratives is precisely used for that purpose, reevaluating the grounds of modernity. According to Lyotard, the postmodern is thus which, in the modern configuration, "puts forward the unpresentable ; that which denies itself the solace of good forms, the consensus of a taste [...]" (Lyotard, 1998: 31). By composing images of modernity, unveiling modern incompleteness, postmodernists desire to scrutinize the deleterious aspects inscribed in its structure and revealed in the course of modern history. There are no prescriptive obligations, neither given judgment about the modern question; there is only an appeal to judge again. Not closing history constitutes an opportunity for giving strength to the residual critical aspects in modern thought. Redeploying historicity is viewed as an imperative when judgment seems not to be required anymore, since modernity has supposedly reached its ending conclusion. Consequently, the postmodern moment constitutes a reflexive attitude, spacing from where the modern forms and values could be recomposed and reanimated. A too strict periodization does not really correspond to the spirit of this subtle gesture. Postmodern authors such as Foucault criticized the epochal concept because it fundamentally dissimulates the plurality of history, inaudible voices of minorities and powerless, silenced in the triumphant story-telling of the winners and powerful holders of society (Foucault, 1969). On a more philosophical basis, Lyotard agrees with this criticism, in so far as historico-politics just presents case or examples, but never schemes (Lyotard, 1986). The historical sequences only offer us data, signs to be interpreted. He therefore thinks we should substitute the totality of History for an enthusiast interpretation of historical signs. From the fission of the end flows the multiplication of heterogeneous finalities, which are directly related to inventiveness and creation, within and by history.

The historiographic work is surely a task for many generations, given the fact that most of the historical transition times are definitely delimitated a posteriori. The conclusive debate about modernity versus postmodernity is far ahead from us. What stays productive for Lyotard, is the re-opening of the modern, as re-formulated according to contemporary modalities. The Rereading and Rewriting's notions represent ways of avoiding periodization, they moreover underline the hermeneutic motif of postmodern thought. Lyotard emphasizes that anamnesis and anamorphosis processes better symbolize the postmodern gesture (Lyotard, 1991). On the one hand, it means that we should remind modern ideals by re-reading them - anamnesis. On the other hand, it means we should change or transfigure the modern forms through anamorphosis. The act of re-writing can be better understood with the Freudian notion of durcharbeitung, perlaboration or "working-through" the event. Lyotard takes up from Freud 
three distinct moments of therapy, which are repetition, remembrance and perlaboration. Oblivion engenders repetition, as we forget what cause or caused the disease. Remembrance consists in the awareness rising of the forgotten past. Perlaboration is what may bring together the three temporal dimensions of time, linking the living past to the understanding of the present, so that these elements can be integrated to conceive a future, without the reiteration of pathological features. The working-through has no other goal than healthiness; it stands for an ethico-political mechanism that will go into every scales of modernity: ideologies, philosophies, governance practices, political or historical events. The perlaboration is a never-ending dialogical work which is nevertheless driven by an imperious finality. It is obvious that postmodernists interpret some items of modern thought as pathologies that have materialized within modern history and societies. Thus, there is an attempt to notice and purify all the false prescriptive devices underlined by modern genealogies. Postmodern re-reading aims at re-writing and erasing what is representative of any forms of violence and domination, in politics, separation and reduction, in epistemology.

All the postmodern criticisms of modernity put in question a "false" civilization opposed to a "real" individual culture. They decrypt the bankruptcy of a certain integrative model of emancipation, which coincided with the collective and systemic task. It signifies that the modernization crisis starts from the high top of society, a lack of positive projection into what represents nowadays the values of civilization. If postmodernism may be described as a spectral fight on the sense of history and modern orientation, it is symptomatic of a struggle on the ways of "saying" and "making" history. The silent revolution of the post- war era has profoundly modified western societies. Technical changes and cultural transition, namely with knowledge dissemination and information networking, has favored a democratization of the historical narration and political governance. Paradoxically, Postmodernist's attempts have been interpreted as serious threats to the democratic edifice or the scientific statute of modern thinking. For modernists, the postmodern moment has no place within modernity, as it would detour the basic objective foundation of science and contradict the political achievements of liberalism and human rights.

\section{Modern prejudices, modernist strategies}

After having clarified the inner logic of postmodern idea, we propose to confront the modernist criticisms with the postmodern hermeneutic we exposed. The first criticism consists in considering the postmodern as an anti-modern movement, that is to say fundamentally reactionary, positioning against Western Humanism. Habermas sustains that denying universality contradicts with the basic making of human rights and strongly damages the conceptualization of progress (Habermas, 1988). Postmodern authors would be fundamentally against modernity, destroying the substantial achievements of liberal and progressive modern thought. 
We have shown however how the postmodern is not appropriate to the gesture of rupture, typical of the modern. Postmodern thinkers seek to identify the authenticity of modernity, reviving the most relevant features of modern thought. They advocate a continuous re-reading and re-writing, which by a specific genealogy, would revitalize the currents of thought that seem to be at the roots of the modern movement itself. They gather what they think to symbolize the most modern fragments. These modern images are supposed to better fit with the modern mind as well as to the most actual trends of modernity. Re-reading and re-writing, therefore, to find this contemporaneity. Following this critical vision, they except to liberate the liberal and progressive thought that have been unveiled in the historical construction of universality. Indeed, one should not blindly subscribe to a socio-historical construction of the universality notion because, with a careful look, we could perceive all the failures and exclusions at the grounds of universality.

Western history has purposely or unintentionally omitted the discontinuities lying into the alleged objective and neutral notion of universality. At this point, we understand how the postmodern philosophical debate is wisely accompanied by a strong awareness of its own historical gesture. Postmodernists carry out an active historic and social interpretation. Since they accomplish this essential rethinking of modernity itself, they are legitimate to ask whether the modern legacy is one with itself. Here, postmodern thinkers address the question of the plurality of modernity, from its origins to its realization in the course of history. More specifically, Foucault stresses, among other distinctions, two types of modernity. The first one is dependent upon a tradition which focused on the meaning of the present, following the path of "ontology of ourselves" (Foucault, 1984). The second one is relative to an analytical tradition that poses the conditions under which a true knowledge is possible. Postmodern scholars embrace the first tradition which stands for a reflexive posture about modern developments, by questioning modernity and its knowledge on a more existential manner, so to say, the being outputs. Positivism could be assimilated to the second tradition, because there is no fundamental question on the social or existential statute of what we find out, but what is essential constitutes how we find this out, the methodological inputs. The postmodern ethos is more consistent with the first tradition, while the modernist thinkers refer themselves as being the inheritors of the second tradition - holders and defenders of truth. It is not surprising that these latter refuse the ontological criticism of modernity enounced by postmodern theory. If the modernists would accept the ontological critic as a postulate for discussion, they would have to reevaluate the foundations of knowledge on which their methodologies are based, on which modernization has been established. In fact, the debate seems to be impossible as we basically face two different registers of discourse: ethical and analytical, subjective and objective or qualitative and quantitative. Thus, modernists deny postmodern criticisms because they maintain that postmodern knowledge is not sufficiently valid relatively to their analytical requirements.

The second criticism consequently results from this opposition. Postmodern knowledge and methodologies would be fundamentally anti-scientific. But if we closely examine postmodern epistemology, we do not notice any attempts to roughly subvert critical 
thinking and modern scientific outlooks. On the contrary, postmodern theory indicates a very clear willingness to include and extend, within social sciences, the new scientific discoveries in physics or biology. Lyotard underlines himself that the questioning of reason, and scientific pretensions for truth, ultimately derives from the inherent logic of the scientific approach itself, which is the auto-application of scientific requirements of truth to this requirement itself (Lyotard, 1979).

After deconstruction, we should not see rationality as being lessened but rather as being reinforced and enlarged. This stance is explicitly contained in the complexity paradigm. For example, perspectivism intends to enhance referential depth. The search for instabilities never gets rid of the quest for objectivity. Postmodern epistemology is precisely about an examination of the conditions of knowledge under updated scientific notions such as incompleteness, indeterminacy, uncertainty. We are therefore in a supplement of modern science but never in its mere destruction, like some have awkwardly or wrongly assumed. It certainly helps fostering Science in the comprehension of the world; it may be interpreted as a moment that consolidates Science since it contributes to the creation of new modes of legitimacy. The intent of Lyotard's writing of The Postmodern condition was indeed to deliver a book deeply engaged in the finding of these new modes of legitimacy for science.

\section{The postmodern as a modern phenomenon: a critical analysis}

Rather than excluding postmodernism from scientific debates, one shall read the texts and understand the innovative character of the postmodern posture. Beyond any attempts of delegitimization, postmodern representations are symptomatic of the state of modernity. They are significant of deep-long rooted trends that have been at work within modernity and crystallized nowadays under the postmodern banner. Postmodern conceptualizations offer us a standpoint where to question what remains of modern spirit into our contemporary era.

When we read the texts, what strikes us most, lies in the fact that we observe a survival of modern ideals into postmodern world view. On many aspects, we can affirm that the postmodern current incarnates a survival of modern utopia, but a forgotten modernity, a covered up modernity. We should never neglect that modernity contains many faces, there is a profound uncertainty on its contours or limits that have constituted its strength to redefine itself, but that besides made of it an instrumental object. There exists a field of symbolic struggles on modernity which largely irrigates a political debate where the modern issue as such is rarely addressed. In esthetics, Jameson remarks for example how postmodernism implies a restructuration of some features that were already present in modernism, but in which they were minor, marginalized, secondary (Jameson, 1983). These features become determinant features into postmodern cultural production. In philosophy, the emphasis is put on the notion of becoming or the plasticity of reason. Modern values find a new configuration into postmodern theory, as it recaptures the cult of novelty, the modern injunction to exceed itself and 
to go beyond its own limits, the spirit of change and innovation. In fact, the word "postmodern" appears in social space when some avant-garde authors try to describe, within modernity, the current epistemological, technical and social trends of society. Sometimes, these descriptions embody fundamental transition compared to modern structures, sometimes it shows the necessity of changes, and sometimes the changes can only be understood beyond the specific modern epistemology. To be postmodern is to delimit these actual changes. To be postmodernist is to advocate for these changes.

To a certain extent, as we have argued, the postmodern is the modern reflection applied to itself. But, when we understand postmodern thought in this cultural frame, we have no answer for the characterization of postmodernity as a new era, while many authors embarked in this multidimensional and descriptive figuration. We could surely analyse some fundamental ruptures within various fields or into epistemological frames that indicate the transition path. Nevertheless, if we desire to be sharp about the native outlook that emerged with the postmodern issue, we should note that, according to Lyotard, Postmodernity is not a new age, but the rewriting of some of the features claimed by modernity (Lyotard, 1991). As a consequence, we could interpret Postmodernity not as a myth but as a space wherein to project our imaginaries into another era. That is for instance the position of Jameson. He views the postmodern as an essential spacing of the modern in which to deploy a politics of aesthetic representation with an ethical vocation (Jameson, 1994). Indeed each discourse on Postmodernity reveals the investment of a symbolic space. Representing postmodern society is a postmodern representation in itself. The political strength of postmodernism has to be found into the incapacity of defining Postmodernity because the unpresentable holds an esthetical force that stimulates political imagination.

In conclusion, we would like to underline that it is necessary to go beyond the frontiers that have been raised. No rigid dichotomy or dualism can explain both the modern spirit and the postmodern posture. These two elements are too assembled that it remains useless to separate them. We attempt to demonstrate their complementary quality. The modern/postmodern divide may result from the default of communicative practices within scientific community; it may be a symptom of doomed strategies for hegemony. The polemics engendered by postmodern theory could be related to the tricky posture they adopt, which sometimes disconcerts mainstream scientific schemes of argumentation, discussion, and confrontation. Nonetheless, the issues that have been treated by postmodern theory raise fundamental questions for political and epistemological modernity. The seriousness of these questions can explain why it is easier to disqualify the postmodern criticisms than answering them without any intellectual deformations. The hysterical nature of the debate probably finds an explanation in the significance of their criticism concerning the statute of modernity. It is indeed significant of something else than the true extent of transition. Much more, it sheds light on the fact that we lost a clear understanding of contemporaneity, we do not visualize how society is nowadays precisely shaped and can be shaped. It highly signifies and underlines that we are not able to grasp or seize our era, a regime of dispossession. Post-historicity constitutes a modern 
aporia which destabilizes Science and the Humanist project, which were modern presuppositions. We should indeed cognitively master the whole set of phenomena but the motifs of our actions are beyond our comprehensions, they escaped from us. On a technical level, History has rapidly accelerated but we seem to be unable to describe its inner logic. As civilization, we are taken into an extreme complexity, which produces increasing difficulties to figure out the whole set of changes we experience: interconnection of systems, deployment of plural logics, always more rapid technical implementations.

While modernity place men as actor of history in its philosophical project, postmodern men gradually realize that his pretensions to know and to be actor of history are being substantially nuanced. The multiplicity of intermediate links that have appeared takes the individual away from the motifs of his own actions and the responsibilities of his acts. The feeling is widespread that reality follows its own line and escapes from our control. The postmodern condition is characterized by entropy. It symbolizes a dispersion of cognitive and practical references, the bursting of a conceptual unity, the fission of an ethical end or the lost of humanist finality into development due to the development itself. Here, the disenchanted modernity of Weber takes a new but maybe different form. It is no more the destruction of beliefs and myths produced by rationalization. It is instead now a disenchantment descended on reason itself. After all it may be part of a step into the process of rationalization to question itself. In his definition of the quaternary era, Mills shows that its main ideological trait consists in challenging the idea of reason and liberty (Mills, 1959).

Postmodern thought participated to this endeavor because they question the capacity of reason to target reality and its ability to achieve freedom for people. In fact, what makes the controversy so sensitive is centrally that postmodernism may correspond to a moment in western history, a historical moment that is inscribed within the structure of both reason and liberal thought. Historically, we have witnessed a collective liberation process that have questioned and even destroyed all the transcendental features: magical thought, divinity, empires, divine law embedded in kings, personification of power with dictatorship, and somehow now representative institutions. But Science and scientism have not yet been under much debate. Through its technical and economic configuration, performative reason remains one the main contemporary features ordering the conduct of human lives. This is time to deconstruct reason so that human conduct can really rely on their experience of freedom and their own individual choices. The postmodern moment is directed toward this individual liberation. By getting away from all the transcendental signified the postmodern dives into the underlying signifier process which institutes the world, that is under which knowledge and perceptive mechanisms can we understand the socio-construction of reality. From the own reason questioning, it perhaps aims at reaching the naked immanence itself, the pure process of experience. With no doubt, it is probably at this precise moment that postmodernity embodies modernity at its emerging state. 


\section{Bibliography}

Beck, U. (1992) Risk Society: Towards a New Modernity, London: Sage.

Brunette, P. \& Wills, D. (eds.) (1994) Deconstruction and the Visual Arts, Cambridge: Cambridge University Press.

Deleuze, G. (1985) Cinéma Tome II : L'image-temps, Paris: Minuit.

Derrida, J. (1967) L'Écriture et la différence, Paris : Seuil.

Derrida, J. (1993) Spectres de Marx. L'Etat de la dette, le travail de deuil et la nouvelle internationale, Paris: Minuit.

Foucault, M. (1969) L'Archéologie du savoir, Paris: Gallimard.

Foucault, M. (1971) L'Ordre du discours, Paris: Gallimard.

Foucault, M. (1984), “Qu'est-ce que les Lumières?” in Dits et ecrits, volume IV, Paris: Gallimard, 1994, pp. 562-578.

Fukuyama, F. (1992), The End of History and The Last man, New York: Penguin.

Giddens, A. (1991) The Consequences of Modernity, Cambridge: Polity Press.

Habermas, J. (1988) Le Discours philosophique de la modernité, Paris: Gallimard.

Jameson, F. (1983) "Postmodernism and Consumer Society" in Foster H. (eds.) (1983) The Anti-Aesthetic: Essays on Postmodern Culture, Port Townsend: Bay Press, pp. 111-125.

Jameson, F. (1994) Postmodernism or The Cultural Logic of Late Capitalism, Duke: University Press.

Lipovetsky, G. (1989) L'Ère du vide: Essais sur l'individualisme contemporain, Paris: Folio.

Lyotard, J.-F. (1979) La Condition postmoderne: rapport sur le savoir, Paris : Minuit.

Lyotard, J.-F (1984) Le Différend, Paris: Minuit.

Lyotard, J.-F. (1986) L'Enthousiasme ou La critique kantienne de l'histoire, Paris: Galilée.

Lyotard, J.-F. (1988) Le Postmodernisme expliqué aux enfants. Correspondances 1982-1985, Paris: Galilée. Lyotard, J.-F. (1988a) "Réécrire la modernité", Les Cahiers de philosophie, 5.

Lyotard, J.-F. (1988b) Le Postmodernisme expliqué aux enfants. Correspondances 1982-1985, Paris: Galilée.

Lyotard, J.-F. (1991) The Inhuman, Stanford: Stanford University Press [1988].

Mills, C. W. (1997) L'Imagination sociologique, Paris: La Découverte [1959].

Morin, E. (1973) Le Paradigme perdu: la nature humaine, Paris: Seuil.

Rorty, R. (1979) Philosophy and the Mirror of Nature, Princeton: Princeton University Press. 